\title{
Modified Snodgrass Repair for Hypospadias: Outcome at a General Surgical Unit
}

\author{
Anwar UI Haque1, Fazli Akbar', Saddar Raheem¹, Muhammad Hussain', Muhammad Nadeem, \\ Khurshid Alam², Kaleemullah', Samiullah¹, Israr UI Haq ${ }^{1}$
}

\begin{abstract}
Background: Hypospadias occurs in around one in 200-300 male live births and is the most common congenital abnormality of the urethra. There are three characteristic features; Firstly the external meatus opens on the underside of the penis or the perineum, secondly the ventral aspect of the prepuce is poorly developed ('hooded prepuce') and thirdly there is usually a ventral deformity of the erect penis (chordee). Many methods have been used to repair hypospadias. We worked on Modified Snodgrass repair for midshaft and distal hypospadias in a General Surgical Unit.

Objective: To study the outcome of Modified Snodgrass Repair with respect to outcome and post operative complications like fistulas, disruption, meatal stenosis, residual chordae ,penile torsion and infections.

Material and Methods: All patients with hypospadias according to exclusion and inclusion criteria admitted to Surgical B unit of Saidu Teaching Hospital from 1st January 2015 to 21st December, 2019 were entered in the study. U shape incision was made around the urethral plate. Urethral incisions were extended to the mid-glans. Urethral plate was incised in center upto midglans. After tubularization of urethral plate and circumferential incision proximal to coronal sulcus from each edge of urethral plate, the penile skin was degloved upto or near to penoscrotal junction depending upon extent of chordee. Neourethra was formed and covered by Dorsal Dartos facial flap which was slit in the centre and brought out to ventral surface by passing the glans through the slit. The child was followed after a week to change dressing and after 10 days to remove catheter and then after one month and three months for checking complications and outcome.

Results: Total of 100 subjects were included in study, $(67 \%)$ having anterior and $(43 \%)$ having middle hypospadias. Mean age was 3.7 years. Complications were recorded in $21 \%$ of patients. Urethro cutaneous fistula in $9 \%$, Total disruption in $1 \%$, Infections in $5 \%$, Meatal stenosis in $2 \%$, Catheter blockage in $2 \%$ and penile torsion occurred in $2 \%$ of patients. $97 \%$ cases had good cosmetic shape. The fistulas were repaired after 6 months in two layers and had satisfactory results.
\end{abstract}

Conclusion: A properly performed Modified Snodgross repair can be performed in General Surgical Unit with reasonable efficacy if expertise is available

Keywords; Hypospadias, urethroplasty, Snodgrass repair, Meatal stenosis, Urethrocutaneous fistula.

This article may be cited as: Haque UA, Akbar F, Raheem S, Husain M, Nadeem M, Alam K, Kaleemullah, Samiullah, Haq UI. Modified Snodgrass Repair for Hypospadias: Outcome at a General Surgical Unit. J Saidu Med Coll Swat 2020;10(2):156-159

\section{INTRODUCTION}

Hypospadias is a condition where the urtethral meatus lies somewhere on the undersurface of penis between tip of penis and perinium. The ventral aspect of the prepuce is poorly developed (hooded prepuce). It may or may not be associated with penile curvature (chordee). It is not an uncommon congenital malformation affecting the male genitalia 1. Hypospadias is present is approximately one in $\mathbf{2 5 0}$ male new borns and there is an increasing incidence of this condition ${ }^{2}$. Familial hypospadias is present in about $7 \%$ cases $^{3,4}$.

As the urethral opening is located anywhere between tip of the penis and the perineum so based on the position of meatus, hypospadias may be anterior, middle or posterior ${ }^{5}$. Anterior hypospadias is further classified into Glandular,

1.Saidu Teaching Hospital, Saidu Sharif, Swat

2.Nawaz Sharif, Kidney Hospital, Swat

Correspondence: Professor Dr. Anwar ul Haque

Incharge Surgical B Unit

Saidu Teaching Hospital/Saidu Medical College

Saidu Sharif.

Email:anwarulhaqmian@gmail.com
Coronal, Sub-coronal and Distal penile hypospadias. Middle hypospadias includes mid penile, and posterior hypospadias includes Proximal penile, Penoscrotal and Perenial ${ }^{6}$.

In Glanular hypospadias the ectopic meatus is placed on the glans penis but proximal to the normal site of the external meatus which is marked by a blind pit.In coronal hypospadias meatus is placed at the junction of the underside of the glans and the body of the penis. In penile and penoscrotal hypospadias meatus is on the underside of the penile shaft. Perineal hypospadiasis is the rarest and most severe abnormality .The scrotum is bifid and the urethra lies between its two halves. The more severe varieties of hypospadias represent an absence of the urethra and corpus spongiosum distal to ectopic opening. The absent structures are represented by a fibrous cord, which deformes the penis in a downward direction(chordee).

More than 300 different procedures have been described for hypospadias repair ${ }^{7}$. No urethroplasty procedure is definitely superior to other. Urethroplasty procedure may be single stage or staged ${ }^{8}$. Techniques for anterior 
hypospadias are single staged, like Snodgrass [TIP] repair, MAGPI, MATHEW, etc. while for posterior hypospadias staged procedures (AVOR BRACKA etc ) are used ${ }^{9,10}$. Being easy and simple procedure with good results and fewer complications, Snodgrass [TIP] repair is the most frequently performed single stage procedure for anterior hypospadias ${ }^{11,12}$. Dartos flap technique like modifications have reduced the rate of complications further ${ }^{13}$.

Commonest complication is urethrocutaneous fistula (> $60 \%$ ) of all complications ${ }^{13}$. Reported incidence of fistula is 0.58 to $16 \%{ }^{14,15}$ while that of meatal stenosis ranges from 0 to $17 \%$. Total disruption, wound infection and urethral stircture are less frequent complications ${ }^{7,16,17}$.

The purpose of our study is to find the outcome of Modified Snodgrass Repair performed by expert hands in a General Surgical Unit.

\section{MATERIALAND METHODS}

In this Prospective study, after taking approval from Institutional Ethical Committee, we recorded data of patients admitted to Surgical 'B' Unit of Saidu Teaching Hospital between $1^{\text {st } J a n ~} 2015$ and $31^{\text {st }}$ Dec 2019 . Sample size was calculated with following formula.

$n=Z^{2} P(1-P) / d^{2}$

where

$\mathrm{n}=$ Sample size

$Z=Z$ statistic for a level of confidence

$\mathrm{P}=$ Expected prevalence or proportion

(if expected prevalence is $20 \%$ then $P=0.2$ ), and

$d=$ Precision(if the precision is $5 \%$, then $d=0.05$ )

Inclusion criteria were all the patients of anterior \& middle hypospadias between age of 1 year to 12 years. Patients with failed surgery before were excluded from the study. Informed consent was taken from parents regarding procedure and study. All operations were performed by F.C.P.S. qualified surgeon having experience of more than ten years, all patients were given General anesthesia and Injection Ceftriaxone was given at induction and then for two days post operatively and then shifted to oral Cefixime for 10 days. Vicryl $5 / 0$ and $6 / 0$ were used for suturing. Vicryl $2 / 0$ was used for stay at glans and later securing the feeding tube of size 6 to $8 \mathrm{Fr}$ used as catheter. After making $U$ shaped incision around the urethral plate and extending the incisions to the mid-glans, the urethral plate was incised in center upto midglans. Circumferential incision was made proximal to coronal sulcus from each edge of urethral plate and the penile skin was degloved upto or near to penoscrotal junction depending upon extent of chordee. Neourethra was formed by tubularization of urethral plate and covered by Dorsal Dartos facial flap which was slit in the centre and brought out to ventral surface by passing the glans through the slit. The child was followed after a week to change dressing and after 10 days to remove catheter and then after one month and three months for checking complications and outcome. A vertically oriented slit like meatus and conical glandular shape and straight urinary stream with no fistulation were considered good outcome. Data analysis was done by SPSS version 22. Age was ordinal variable while various complications like fistula, penile torsion, meatal stenosis, catheter blockage and infection were nominal variables. Independent sample t test was used to compare our outcomes with means of other studies and $p$ value of less than 0.05 was considered stastically significant.

\section{RESULTS}

Total of 100 cases were included in study,(67\%) having anterior and (33\%) having middle hypospadias. Mean age was 3.7 years. Complications were recorded in $21 \%$ of patients. Urethro cutaneous fistula in $9 \%$, total disruption in $1 \%$, Infections in $5 \%$, Meatal stenosis in $2 \%$ ,Catheter blockage in $2 \%$ and penile torsion occured in $2 \%$ of patients. $97 \%$ of patients had good cosmetic shape. The fistulas were repaired after 6 months in two layers and had satisfactory results. Cases of penile torsion were mild and did not need intervention. Meatal stenosis responded to dilatation. 
Table 1. Complications

\begin{tabular}{|l|l|c|}
\hline \multicolumn{2}{|l|}{100} \\
\hline Metal patients & \multicolumn{2}{|c|}{3.7 years } \\
\hline Complications & \multicolumn{2}{|c|}{ Total } \\
\cline { 2 - 3 } & $\begin{array}{l}\text { Urethrocutenous } \\
\text { fistula }\end{array}$ \\
\cline { 2 - 3 } & Total Disruption & $9 \%$ \\
\cline { 2 - 3 } & Meatal stenosis & $21 \%$ \\
\cline { 2 - 3 } & Catheter blockage & $2 \%$ \\
\cline { 2 - 3 } & Penile torsion & $2 \%$ \\
\cline { 2 - 3 } & Infections & $5 \%$ \\
\hline
\end{tabular}

Table 2.Types of hypospadias

\begin{tabular}{|l|l|}
\hline 1. Glandular & $10 \%$ \\
\hline 2. Coronal & $21 \%$ \\
\hline 3. Distal penile & $36 \%$ \\
\hline 4. Mid penile & $33 \%$ \\
\hline
\end{tabular}

\section{DISCUSSION}

The technique of hypospadias repair has been evolving, so none of the current methods is without complications even in the best of hands ${ }^{18}$.This can be judged from the existence of more than 300 different types of surgical procedures for repair. Snodgross repair is the widely practiced procedure for hypospadias because it is simple and easily performed with good cosmetic results. The overall complications rate of the procedure ranges from 0 to $53 \%^{13,19,20}$. Mean age in our study was 3.7 years. In study by Abdullah $\mathrm{F}$ et al, mean age was 4.17 years $^{21}$. A total of $21 \%$ of our patient patients developed various complications. Urethrocutanenous fistula occurred in $9 \%$ cases. In study by Abdullah F et al urethrocutaneous fistula occurred in $11.11 \%$ patients $^{21} .27 \%$ of patients treated with Snodgross repair by Archana $A$ et al developed urethracutenous fistula ${ }^{22}$, while it developed in $2.5 \%$ patients operated by Radi Alsharbaini et $\mathrm{al}^{23}$. Khairi A, reported post Snodgross repair fistula rate of $11.8 \%{ }^{24}$. While in study by Uzair $M$ et al, fistula rate was $9.9 \%{ }^{25}$. In our study dorsal prepucial flap was used in all cases while Alsharbaini et al found that lateral dortos flap was eaisly raised and mobilized to midline and was also a good option in cases in which the child had been circumcised before urethroplasty as there was no prepucial flap ${ }^{23} .1 \%$ of our patients had total disruption of the procedure due to infection, while $5 \%$ developed infection which settled with
IV antibiotics \& dressing. In study by Alsharbaini et al, the urethrocutaneous fistula occurred in $1.6 \%$, while it occurred in $25 \%$ patients operated by Archana et $\mathrm{al}^{22}$. Meatal stenosis occurred in $2 \%$ cases. Snodgross reported the incidence of meatal stenosis of 0 to $1 \%{ }^{26}$. It was $6.3 \%$ in study by Abdullah $\mathrm{F}$ et $\mathrm{al}^{21}$. Upto $20 \%$ chances of meatal stenosis have been reported in some studies ${ }^{27}$.

Final cosmetic results are also important. Penile torsion was minimal in our study just $2 \%$. It occurred in $3 \%$ cases in study by Archana et $\mathrm{al}^{22}$, while it was $2.7 \%$ in study by Wacksman et $\mathrm{al}^{28}$. Shape of penis was satisfactory in $97 \%$ of our cases. $4 \%$ of cases had poor cosmetic results in study by Archana et $\mathrm{al}^{22} .2 \%$ patients had stent blockage which was changed in one patient and stent was removed on $6^{\text {th }}$ day in the other. We compared our complications rate with those of other studies by independent sample t test and $p$ values were more than 0.05 showing no statistically significant difference.

\section{CONCLUSION}

Modified Snodgrass repair has fewer overall complications as compared to other procedures. If performed by expert hands in a General Surgical Unit with proper protocols and gentle tissue handling, the results of Modified Snodgross repair can be encouraging for anterior and middle hypospadias with fewer complications and good cosmetic results. 


\section{REFRENCES}

1. Hinman F Jr, Baskin LS. Hypospadias. In: Hinman's Atlas of Pediatric Urologic Surgery., $2^{\text {nd }}$ ed.Philadelphia:Saunders Elsevuier; 2008. 653-61

2. Kraft KH, Shukla AR, Canning DA. Hypospadias. Urol Clin North Am. 2010;37(2):167-81.

3. Van der Horst HJR, De Wall LL. Hypospadias, all there is to know. Eur J Pediatr.2017 Feb; 176(4):435-441.

4. Van der Zanden LF,van Rooij IA, Feitz WF, Franke B, Knoers NV, Roeleveld N. Aetiology of hypospadias: a systematic review of genes and environment. Hum Reprod Update. 2012 May-jun;18(3):260-83

5. Baskin LS, Ebbers MB. Hypospadias: anatomy,etiology, and technique. J Pediatr Surg. 2006;41(3):463-72.

6. Duckett JW, Gillenwater JY, Grayhack JT, Howards SS: Hypospadias. Adult and pediatric urology, $3^{\text {rd }}$ edn. 1996, 2550-55.

7. Appeadu-Mensah W, Hesse AA, Glover-Addy $H$, Osei-Nketiah S, Etwire V, Sarpong PA. Complications of hypospadias surgery: Experience in a tertiary hospital of a developing country. Afr J Paediatr Surg. 2015 Oct-Dec; 12(4): 211-216.

8. Badaway H, Fahmy A. Single- vs. multistage repair of proximal hypospadias: The dilemma continues. Arab J Urol. 2013 Jun; 11(2): 174-181.

9. Elsayed T, Dawod, Abdulla M, Teleb A et al. One-stage lingual augmented urethroplasty in repair of distal penile hypospadias. Afr J Urol. 2015 Mar; 21(1):0609.

10. Shukla AK, Singh AP, Sharma P, Shukla AK, Singh AP, Sharma P, Shukla J. Two stage repair of proximal hypospadias: Review of 700 cases. J Indian Assoc Pediatr Surg 2017; 22:158-162.

11. Snodgrass WT, Bush N, Cost N. J Pediatr Urol. Tubularized incised plate hypospadias repair for distal hypospadias 2010 Aug; 6(4):408-413.

12. Ibrahim IA. Modified Tubularized incised plate urethroplasty for distal hypospadias without chordate. J Am Sci. 2013 Sept; 9(10):140-145.

13. Basavaraju M,Balaji DK. Choosing an ideal vascular cover for Snodgrass repair. Urol Ann 2017 Oct; 9(4):348-352

14. Cheng EY, Vemulapalli SN, Kropp BP, Pope JC, Furness PD, Kaplan WJ, et al. Snodgrass hypospadias repair with vascularised dartos flap: the perfect repair for virgin case of hypospadias. J Urol 2002; 168:1723-1726.

15. Akmal M, Javed SH, Subhani GM, Jafari AA, Ashraf N, Hussain M, et al. Hypospadias Urologe A. 2007 Dec;46(12):1664-1669.

16. Pfistermuller KL, McArdle AJ, Cuckow PM. Metaanalysis of complication rates of the tabularized incised plate (TIP) repair. J Pediatr Urol. 2015 Apr, 11(2):54-59.
17. Mandal AK, Amilal B. Acute postoperative complications of hypospadias repair.Indian J Urol. 2008 Apr-Jun;24(2):241-248.

18. Bhat A, Mandal AK. Acute postoperative complications of hypospadias repair. Indian journal of urology: IJU: J Urol Soc India. 2008;24(2):241-9.

19. Snodgrass W, Yucel S. Tubularized incised plate urethroplasty for mid shaft and proximal hypospadias repair. J Urol. 2007 Feb; 177(2):698-702.

20. Abolyosr A. Snodgrass hypospadias repair with onlay overlapping double-layered dorsal dartos flap without urethrocutaneous fistula: Experience of 156 cases. J Pediatr Urol. 2010;6:4037-46.

21. Abdullah F,Akhtar WImran M,Rahmanl . Frequency of Urethro-Cutaneous Fistula \& Meatal Stenosis Post Snodgross Repair with Dartos Flap for Hypospadias in Children. Ophthalmology Update.2018 Oct-Dec; 16(4): 904-907.

22. Archana A et al. A study of Complications and outcome of hypospadias repair at a tertiary care hospital of south Gujrat, India . Int Surg J. 2018 May;5(5):1677-1680.

23. Alsharbaini R, Almaramhy H. Snodgrass urethroplasty for hypospadias repair: A retrospective comparison of two variations of the technique. Journal of Taibah University Medical Sciences 2014; 9(1), 6973.

24. Khairi A. Snodgrass repair for distal hypospadias: a review of 75 cases. Ann Pediatr Surg 2012 Sept; 8(1):12-14.

25. Uzair M, Ahmad M, Hussain M, Younas M, Khan K. Frequency of urethrocutenous fistula following Snodgrass hypospadias repair in children. J Postgrad Med Inst 2013; 27(1): 74-77.

26. Snodgrass W. Does tabularized incised plate hypospadias repair create neourethral strictures $\mathrm{J}$ Urol. 1999 Sep; 162(3):1159-1161.

27. Tonvichien L, Niramis R. Tubularized, incised plate urethroplasty in hypospadias repair: experience at Queen Sirikit National Institute of Child Health. J Med Assoc Thai. 2003 Aug; 86(3):522-530.

28. Wacksman J. Use of Hodgson XX (modified Asopa) procedure to correct hypospadias with chordee: surgical technique and results. J Urol. 1986;136(6):1264-5. 